\title{
The Conflict between Paganism and Christianity in Irish Theatre: A Cultural Study of O'Casey's The Drums of Father Ned
}

\author{
Amal Kitishat \\ Department of English, Ajloun University College, Al Balqa’ Applied University, Ajloun, Jordan \\ Hana Fathi Farajallah \\ Department of English, Ajloun University College, Balqa’ Applied University, Ajloun, Jordan
}

\begin{abstract}
While Irish theatre assures that it reflects Irish reality and aims at building a national identity in which religion is a significant marker, the plays of $O$ 'Casey contradict with this tendency. This study aims at discussing the conflict between an anti- Christian and pagan beliefs and Christian values in favor of antiChristianity over Christianity. In this article, the researcher takes O'Casey's The Drums of Father Ned as an example. The study discussed the tension between the pagan and Christian values as represented in the conflict between the pagan and religious characters, represented by Father Fillfogue who is the representative of Christianity; while The Celtic god Angus represents Pagan Celtic anti-Christian religion. Finally, the study proved that $\mathrm{O}^{\prime}$ Casey presented a skeptical attitude toward Christianity and favored pagan Irish local, regional beliefs.
\end{abstract}

Index Terms - Irish drama, Sean O'Casey, Celtic culture, The Drums of Father Ned

\section{INTRODUCTION}

The study aims at investigating the conflict between Pagan and Christian values as represented in O' Casey's The Drums of Father Ned. O' Casey has a major role in the reviving of the Irish cultural identity which was achieved by his drawing on the ancient Irish culture as a major source for his plays. He found in Ireland's Celtic legends, folklore, and pagan beliefs rich sources to emphasize the conflict between paganism and Christianity. An attitude which foreshadows the regional and colonial conflict as well. What the study aims to prove is the hidden conflict between pagan and Christian values in the underlying structure of the play.

O'Casey belongs to a Protestant family from a lower -middle Irish class. He lived in the impoverished slums of Dublin and knew very well what poverty meant. According to Encyclopædia Britannica (2018) Because of this background, O'Casey became occupied with Irish political and national reality, he changed his name from its English version, John Casey, to its Irish form as Sean O'Casey. He showed a great sense of nationalism and learned the Gaelic language.

Many critics discuss O'Casey's attitude toward Christianity. Herbert Coston (1960), states that O'Casey's life in Dublin was full of challenges and "disillusionment faced each new turning," (p.46) which led him to leave Ireland because of his disappointment from the political and social injustice. He found refuge in drama to express his anger and revolt against all forms of authority that deprived the Irish people of having their freedom. A clear example of this kind of plays is The Drums of Father Ned. For instance, Cowasjee (1963) in Sean O'Casey: The man Behind the Plays pinpointed that the play had much "controversy" because it uncovers the authorities that O'Casey was attacking. (Cowasjee, 1963, p.231).

Moreover, in The Theatre of Sean O'Casey, James Moran (2013), presents many incidents reporting the reaction of the Irish audience against O'Casey's irreligious treatment. For example, he reported that Father Gaffney protested against this treatment, because as he claimed that most of his plays were "staged in the full panoply of blasphemous crudity.” (Moran, 2013, p.11.)

Sean O'Casey was known of his sense of Nationalism,; he used drama as a weapon to achieve his goals. Christa Velten (1989) comments on this particular point, she states:

O'Casey has been controversial from the time when he took his pen as a weapon to fight for Ireland's freedom, for which he chose the stage in the first place. He did not fight for a freedom that exhausted itself in the attainment of Ireland's political independence - even though this was undoubtedly one of his foremost alms, in the same way as it was the aim of the numerous Irish nationalist movements of his time. (Velten, 1989, p.59)

Thus, the study sheds light on the tension between the pagan and Christian values as represented in the conflict between the pagan and religious characters. In other words, the study aims to prove that though O'Casey stressed the 
significant elements in the Irish identity, yet when it comes to religion, he revealed a skeptical attitude toward Catholic Christianity and favored pagan Irish local, regional beliefs.

\section{The Conflict Between Pagan AND Christian VAlues}

The underlying structure of the play has revealed the conflict between pagan and religious ideas. Concerning the tension between the pagan and Christian values, it is important to point out to the fact that pagan gods dominate the action of the play. Father Ned is seen as a preacher who reminds the youth of Ireland of their legendary heroic past. There is an apparent conflict between the pagan and religious characters in which Father Fillfogue is the representative of Christianity

Focussing on the role of Pagan gods in The Drums of Father Ned; the most important god is Angus the Celtic deity of youth governs the play's actions. His influence is seen on the young people of the town. His attitudes and actions are represented throughout The Drums of Father Ned (Rollins, 1985, p. 86). Angus, the Celtic deity of youth, is defined as:

Angus (Aengus, Oengus) was in Celtic myth the natural son of Dagda by Boann and was often referred to as Macau or the young God, the Celtic Eros. The deity of fertility and spring, he was beautiful and ever young, sleeping through the winter and wakening each spring. A musician Angus, (his name in Celtic means excellence or virtue) was always associated with his sweet music. In some instances his kisses became birds, and although they remained invisible, they whispered thoughts of love to young people. His abode was the fairy palace at Brugh on the banks of the River Boyne. (Jacobs, 1962, p.97) .

The man of the pike and the carpenter are working together preparing the stages and the Tostal posters for the festival. According to father Ned who urges the people to retrieve their Celtic culture, The Man of the pike chose six Irish figures that will be drawn on signs to be projected in the festival. Those six figures are selected from because every character is associated with a quality that present Ireland lacks. Therefore, this show will be of a significant role since each one of these Irish figures contributes to the country's benefit. Hence, he is one of the characters that the young people want to paint with the other six Irish Celtic sources:

I wonder why Father Ned or Michael either wanted to show th' world th' kissers of th' old Irish gods and heroes? [...], a pillar holdin' up the head of Dunbo-whoever he was-a harp at th' pillar's butt, played be shadowy hands, th' thin string, sho win' throu th' white twinklin' fingers; an' this one I'm doin' who was this kid. (O'Casey, 1960, act. II, p. 32).

Accordingly, it is clear that the six figures that O'Casey thinks are necessary to be impeded in the Irish daily life since Ireland is in great necessity for them. Those figures stand for warriors, kings, and churchmen who combine characters that Father Ned wished to be preserved and remembered by the Irish youth, represent Ireland's future. (Rollins, 1985, p.88)

It is necessary then to give a brief account of each character that O'Casey has chosen to be presented in the Irish cultural heritage. The first Celtic figure is Conn of the Hundred Battles.; apparently his name reveals his identity this might be due to the fact that he is a mighty Warrior in Irish mythology, "One of the high kings of Tara whose miraculous visit to Tir Na Og (my emphasis), the Celtic Paradise of the gods is[ ---] a sovereignty for the high kings in Ireland"(Ibid). Consequently, this king stands for heroism that O'Casey thinks that is needed in contemporary Ireland. The second figure is a real figure that is well-known in Irish history. Brian Boru is a powerful Irish ruler who was able to bring order and unity upon the whole countries of Ireland. In the play, we are equipped with a brief hint about this king's role in the history of Ireland. In the play, O'Casey says:

From the ninth century onwards, there were several attempts by great kings to establish themselves as masters of the whole country by taking hostages from Provincial kings. Brian Boru finally realized this ambition in the loss, and from then until the Norman Invasion, the kingship of Ireland, at least as an idea, may have said to have prevailed. (O'Casey, 1960, Act ii, p. 40)

This figure gives an impression of what kind of ruler O'Casey wants Ireland to have. He hopes Ireland to have a powerful leader who can unify the Irish fighting countries against any colonial powers.

\section{O'CASEY'S ATTITUDE TOWARD CHRISTIANITY}

One major feature of O'Casey character is his skepticism toward Christianity. O'Casey comments on his religious beliefs, "I'm an atheist, thank God." (David Krause,1966,p.145). When he was asked about if he still considered himself a believer or not, O'Casey answered, "I never lost my faith, I round it, round it when Jim Larkin came to Dublin[...] I round it in Jim's great socialist motto: 'An injury to one is the concern of all.'"(ibid). Taking declaration into consideration, the study aims to examine religious beliefs in O'Casey by linking them to his portrayal of these figures in his plays.

In most of his plays, O'Casey's made the religious hypocrisy as his target. He attacked with a high degree of scornful criticism all forms of power that deprived a man of injustice and freedom. This made him an object for the religious men attacks; especially from the part of Catholic religious believers. In this context, it is necessary to shed light on the position of The Irish Catholic Church.

The Catholic Church has a very powerful existence in the Irish society; Mc Diarmidi comments on the role of the Catholic Church in Ireland, she says: 
Although the Catholic Church in Ireland was not a nation, it functioned to some extent as a state within a state. A large part, perhaps the central part of its glory and power, was its huge network of social service institutions: orphanages, hospitals, asylums, primary schools [...] that performed many state functions. (Mc Diamide, 2005, p.127)

Taking this reality into consideration, any attempt to criticize the church was considered as a taboo, and this explains why many riots happened after any play that even tackled this sensitive issue. O'Casey's plays show a severe criticism against the bad aspects of Irish society; especially religious hypocrisy. Influenced by socialism, O'Casey calls for equality between classes, and demand social reform especially for the poor working class to whom he belongs. Though he was aware that criticizing religious and political figures was a taboo, however; he was like many of the Abbey dramatists discussed the ills of the Irish society by choosing them as themes to be presented on the Stage of The Abbey Theatre.

As a socialist, O'Casey tries to reach a compromise between Christianity and Marxism; Moran argues that " $\mathrm{t}] \mathrm{here}$ might be something sacred about the Communist desire for equality, with O'Casey presenting the avowedly atheist philosophy of the USSR in a language that Christians might understand and find appealing."In other words, O'Casey tries to make alignment between Marxism and Christianity by using "the rhetorical tropes and philosophical ideas associated with their faith in order to redirect attention to the more worthwhile goal of achieving global justice and personal fulfillment in this world rather than the next."(Moran, 2013, p.11)

Concerning this point, in Sean O'Casey on the Absurdity of War, Christa Velten elaborates on how O'Casey's drama played a great role in revealing the contradictions inside the Irish society; she states:

The road to freedom leads through crises that develop from the confrontation with one's harsh reality. Not always were the Abbey authors succeed in their attempts to open up the eyes of the public and to sharpen their senses for the perception of their true problems. Often enough the majority of the Irish sought refuge behind their absolute trinity of taboos: Religion, Sexuality, and Patriotism pouring their wrath onto those who lashed out against Ignorance, bigotry, and complacency, onto those who tried to arouse pity and compassion. Thus James Joyce uses the image of the old sow eating her farrow, in order to denote his country's hysteric aggressiveness towards its geniuses. (Velten, 1989, pp59-60)

However; he was disappointed due to the tension between the political trends and movements in his days, he expressed his dissatisfaction of the Irish political order in his plays. To do so, he focused his efforts on describing the life of the poor Dubliners in the so-called Dublin Trilogy which is a tragicomic dramatic presentation that reflect his interest for his fellow slum inhabitants, realizing that they were them as impotent of giving a socialist dimension to the Irish cause, "but at the same time admirable for their unconquerable spirit." (Britannica Encyclopedia)

Of the aspects that O'Casey had criticized is the increasing power of the Catholic Church and the tension between religious and secular. One of the major figures in his plays is the representative of the religious institution, that is the Church. O'Casey presented Christianity in the figure of the Father Fillfogue. The existence of such a religious figure is of great importance because it clarified O'Casey's attitude toward religion. He did not mind people believing in religion, but he mocked the ill deeds that the religious men committed in the name of religion. For instance, when people revolted against poverty, the religious men ask them to accept it as part of "Gods divine will."(Krause,1984, p.139). O'Casey wanted to have reliable holy men exactly as Columcille who is placed among the most significant Irish character. He is introduced as a very influential Irish figure in both the religious and the political realms of early Ireland. He is known as Saint Columba who is a "powerful sixth-century churchman in developing Irish church which established an important monastic sanctuary at long. (Ibid). O'Casey has been challenged regarding his skeptical attitude toward the Catholic Church. However, this assumption is not valid, since O'Casey never attempted to mock religion as a system, but he wanted to criticize the bad practice of those who pretended to be religious. He declared his attitude to religion, and he states that for a long time, O'Casey had lived among the poor Catholic slum dwellers of Dublin. He considered himself as one of them, except their Catholic faith. (Krause, 1984, p. 142)

So, it is clear then that O'Casey has never been against religion; his choice of Saint Columba is a strong piece of evidence against anyone who claims O'Casey's passive attitude to the religious men. The last two Irish heroes are Cuchulain and Dunbo. The former character is well known since he is the greatest hero in the Ulster cycle of Celtic epic tales. His manner of dying, (when he ties himself to a rock to die on his feet), is considered to be a symbol of heroic dignity. (Rollins, 1985, p. 87) The last character was Dunbo, (Dunn-Bo), a mythical Irish hero who is killed in "the battle of Almu, his head continued to sing on the battlefield long after the battle had ended." (Ibid). When the paintings become ready, the young people begin the preparations for the tostal.

In the play, O'Casey highlighted the tension between those who are in power and the ordinary Irish people. A clear example is when the representatives of political and religious forces declared their objection of organizing a festival that celebrates the old heroes. For instance, the mayor and his deputy who represented the governmental authorities object the saying that 'It's the waste of time Mc Gilligan and a waste of money; you Won't resuscitate us be bringin' back shaded as O'men who done an' said things in a tormented time of long ago that have no bearin' on the life we live today."(O'Casey ,1960,p.30)

Another character who expresses his disapproval of organizing such a festival claims that "things here have aged too long for us to try to make them young again." This assumption has been immediately denied by one of the young girls who prepare for the festival saying: "Old fields can still bring forth new corn, say, Father Ned." (O’Casey ,1960, p.85). Father Ned is the young priest who directed the young men and women in the play. He was not seen on the stage, but 
his instructions were reported to the audience by the other young men and women. Also, the sound of his drums assured the audience of his presence. This symbolic presence of Father Ned made Father Fillfogue, the representative of Christian religious men deny his real existence:

!Who is this Father Ned? Where is he an' who is he? My breath is gone. Where is that Father Ned of yours? At the Tostal flag-pole; at the town hall, in the main street watching the window-boxes go up; yet I found him nowhere! Who is he? (O'Casey, 1960, p.43)

Father Fillgogue's search is of no use since Father Ned can be seen as a personification of the life force of freedom and joy in love and life. (Rollins, 1985, p. 85). However, O'Casey's use of Irish figure with their different perspective implies the urgency of Ireland's transformation by anew heroic, economic, political, religious leaders. This is the gist of the play that the study concluded. By the last act, the youth of Ireland followed the drums of Father Ned expect the three figures who are representative of the political and religious authorities. This fact forced them to admit that Ireland has revolted against the authorities that deny them from having freedom .It also an implication of Ireland's aspiration toward a new reality, and a positive futuristic change. (O'Casey, 1960, p. 53) Therefore, the play ends with the defeat of the old passive authorities and the victory of youth. In the play, O'Casey offers us his dream of a New Ireland that has the Gaelic spirit linked with its modern way of life.

O'Casey succeeded in transferring the Irish peasants' life from a realistic depiction into a universal worldwide appeal. O'Casey's had a futuristic vision of Ireland; he asserted the necessity of having great influential leaders like Brian Boru, Conn of the hundred battles, and like the grand hero Cuchulain.

He wanted the spirit of Angus (The Celtic god of youth) to offer Ireland a permanent youth and fertility. The image of Saint Colmcille asserts his dream of true saints and religious men of present Ireland; this is the New Ireland that O'Casey longs for having. His vision of Ireland free from poverty, illiteracy, false nationalism, religious and racist discrimination is what makes him different from any other Irish dramatist. In other words, in The Drums of Father Ned, O'Casey identifies the significant problems in Ireland with a satirical criticism of the negative aspects of a country that is known to have a tremendous heroic culture and heritage.

Also, he maintained to have the Irish themes clear in all of his works, but at the same time, they indicated severe matters that are of universal interests. O'Casey celebrated the life of the individuals, especially those Irish peasants, who were presented as far away from religion; though they claimed to be religious. This created a kind of a hidden conflict where Christianity did not have power if compared with Celtic pagan beliefs that many Irish people still considered to have a holy presence. Within this nihilistic vision of man, O'Casey presents a pessimistic view of the future; it is like schizophrenia that still has a function in Irish society. In other words, O' Casey presented a skeptical vision of the future, where modern Irish man seems a weak creature full of contradictions unarmed against the political and cultural challenges of the Post-colonial Ireland.

\section{CONCLUSION}

By introducing the Conflict between Paganism and Christianity as a major theme in The Drums of Father Ned, O' Casey succeeded in achieving a multipurpose function: the first is of a cultural aesthetic value which is manifested in his using the Irish Celtic sources of the post-colonial Ireland as the source of most of his plays. This task is of great significance because of its cultural as well as national significance. It functions as backfire against the cultural and religious dilemma. O'Casey was able to bring the ancient Celtic pagan beliefs of the pre-colonial Ireland back to life. The second function was to foster the loyalty and sense of nationalism of the Irish people away from any dominance of any power that deprived people of their freedom including religion.

Therefore, the importance of the Irish theatre transcends the limitations of regionalism by the tremendous efforts of both O' Casey in his treatment of the Pagan Celtic material so brilliantly. Finally, the study proved that O'Casey presented a skeptical attitude toward Christianity and favored old local Irish regional culture over Christianity. To sum up, O'Casey has been considered as a controversial figure who employed theatre as a powerful weapon in his war against all forms of injustice and inequality because he believed that poverty and ignorance and religious hypocrisy are Ireland's major enemies.

\section{REFERENCES}

[1] Atkinson, Brooks, ed. (1974). The Final Curtain. Conversation with Sean O'Casey. Eds. E.H. Mikhai1 and John O'Riordon. London: Macmillan.

[2] Ayling, Ronald. (1985). "Character Control and Distancing Effects". In Sean O'Casey: The Dublin Trilogy. A Case Book. London: Macmillan. Pp. 171-188.

[3] Ayling, Ronald. (1991). Seven Plays by Sean O'Casey, London, Macmillan.

[4] Darin, Doris. (1946). Sean O'Casey. New York: Frederic Unger Publishing Co.

[5] Donoghue, Denis. (1976). The Sewanee Review 84. Winter. Pp. 129- 33.

[6] Donoghue, Denis. (1985). Peacocks and Mothers: Theme and Dramatic Metaphor. Sean O 'Casey: The Dublin Trilogy. A Case Book. Ed. Ronald Ayling. London: Macmillan. Pp. $111-121$.

[7] Ferriter, Diarmuid. (2004). The Transformation of Ireland. New York, NY: Overlook Press.

[8] Heidenreich-Krawschak, Regina. (1978). The critical reception of Sean O'Casey in Berlin Since 1953. In Sean O'Casey Review, 
5(1) Pp. 55-68.

[9] Jacobs, Gertrude. (1962). Dictionary of Mythology, Folklore, and Symbol. New York: Scarecrow Press.

[10] Kitishat, Amal Riyadh. (2012). Colonialism and the recreation of identity: The Irish Theatre as a Case Study. In Journal of Language and Culture. Vol. 3(5). Pp. 83-86.

[11] Krawschak, Regina Heidenreich. (1978). Critical Reception of Sean O'Casey in Berlin Since 1953.The Sean O'Casey Review, Vol. 5(1), pp. 55-68.

[12] Krause, David. (1966).Towards the End. The Sting and the Twinkle: The World of Sean O'Casey. Ed. Sean Mc Cann. London: The New English Library Ltd.pp. 137-156.

[13] Krause, David. (1982). The Profane Book of Irish Comedy, Ithaca, Cornell Un. Press.

[14] Krause, David. (1984). The Risen O'Casey: Some Marxist and Irish Ironies. O'Casey Annual 3, pp. 43-62.

[15] Kronenberg, Louis. (1952). The Thread of Laughter, New York: Hill \& Wang.

[16] Mc Diarmide, Lucy. (2005).The Irish Art of Controversy. Ithaca and London: Cornell University Press.

[17] Moran. James. (2013). The Theatre of Sean O'Casey. London: Bloomsbury.

[18] O'Casey, Sean. (1960). The Drums of Father Ned. London and York: Macmillan.

[19] Pilkington L. (2004). Historicizing is not Enough: Recent Developments and Trends in Irish Theatre History. Modern Drama. Winter, XLVIII,4:721-731.

[20] Rollins, G.R. Ronal. (1985). The Drums of Father Ned: Celtic Heroes and Harps and the Merry Mummers of Modern Ireland. Robert Rowling (ed) In $O^{\prime}$ Casey Annual, no 4. London: Macmillan.

[21] Saros, Cowasjee. (1963). Sean O'Casey: The Man Behind the Plays. London: Oliver \& Boyd.

[22] The Editors of Encyclopedia Britannica. (2018). Sean O'Casey. Encyclopædia Britannica. Retrieved on January 1/2019, https://www.britannica.com/biography/Sean-OCasey.

[23] Thomson, Laurence. (1974). The Rebel Who Never Retired. The Sting and the Twinkle: Conversations with Sean O'Casey. London: Macmillan. Pp. 1-16.

[24] Thomson, William Irwin. (1988). "Easter 1916 - O'Casey's w. Naturalistic Image. In Sean O'Casey: The Dublin. A Case Book. Ed. Ronald Ayling. London: Macmillan.Pp. 154-165.

[25] Velten, C. (1988). Sean O'Casey on the Absurdity of War: The Silver Tassie: On the Background of O'Casey's Life and Philosophy. In Genet, J., \& Hellegouarc'h, W. (Eds.), Studies on Sean O'Casey. Presses Universitaires de Caen. Doi:10.4000/books.puc. 12 .

Amal R. Kitishat (Correspondent author): born in Salt city/The Hashemite Kingdom of Jordan in 26 of May 1970. She obtained a Ph.D. in English literature from Cairo University in 2006. She is a specialist in modern and contemporary drama.

She is an Associate Professor of English Literature, a specialist in contemporary and modern English \&Irish drama. Formerly, she held the position of Head of Department of English Language and Basic Sciences at Al Balqa Applied University \Ajloun -Jordan. Currently she is a staff member in Faculty of Arts and Head of Scientific Research Unit. Her interests in scholarship include Orientalism, English and Irish drama and literary criticism; she has published many books and articles in the field of English literary studies.

Dr. Kitishat is a member in many literary professional societies such as ALECSO - Arab League Educational, Cultural and Scientific Organization which belongs to the Arab League. Dr. Kitishat is a referee for many academic journals as well as a representative for the department of English in the Deanship of Scientific Research Unit in Faculty of Arts.

Hanaa Fathi Farajallah (Co-author) was born in the United Arab Emirates on 24/ 3 / 1979. Farajallah has a Bachelor Degree in English Language and Literature was obtained in 2002 from Al-al Bayt University, Mafraq, Jordan. The Master Degree in English Literature and Criticism was gained in 2004 from Yarmouk University, Irbid, Jordan. The major field of study is literature and criticism. She works as an INSTRUCTOR at Department of English Language and Literature, Ajloun University College, Balqa' Applied University. Formerly, she worked as FULL-TIME LECTURER at Department of English Language and Literature, Irbid National University from 2007-2012. She published many articles in the field of English Literature. 